\section{Notaire}

Vol. 5 No. 1, Februari 2022
e-ISSN: 2655-9404

p-ISSN: 2721-8376

DOI: $10.20473 /$ ntr.v5i1.32708

Article history: Submitted 9 January 2022; Accepted 18 February 2022; Available online 24 February 2022.

\title{
Analisis Hukum Pemberian Hak Pengelolaan yang Berasal dari Tanah Ulayat Pasca Terbitnya Undang-Undang Cipta Kerja
}

\author{
Dewi Nawang Wulan", Veronica Tjokroaminoto*, Abdul Ghofur** \\ dewi.nawang.wulan-2020@fh.unair.ac.id \\ *Universitas Airlangga \\ **Universitas Hang Tuah
}

\begin{abstract}
Rights of Management are, in hierarchy, part of the right to control the state where some of its authority is given to the rights holder. After the Job Creation Law was enacted, several provisions regarding land rights show changes in rules, not least the affirmation of Management Rights that can occur on Ulayat Land, which causes a clash of the concept of Land Management Rights and the concept of Ulayat Land. Considering the Right of Management Land is the embodiment of some of the right to control the state as contained in Article 33 paragraph (3) year 1945 Constitution of the Republic of Indonesia juncto Article 2 paragraph (1) of Law No. 5 year 1960 on the Basic Rules of Agrarian with Ulayat Land which is part of the Ulayat Rights of indigenous peoples whose existence is recognized in Article 3 and Article 5 of the UUPA. Such a conception needs to be analyzed using the methodology of the legal approach and the concept approach related to the policy of regulating Land Management Rights derived from the Ulayat Land. By paying attention to the existing rules in the UUPA and the legal concept of the Right of Management Land and Ulayat Land, there needs to be a release of Ulayat Rights to the Ulayat Land so that the Ulayat Land becomes State Land and can be granted Land Management Rights on it.

Keywords: Right of Management; Ulayat Land; Job Creation Act.
\end{abstract}

\begin{abstract}
Abstrak
Hak Pengelolaan secara hirarki merupakan bagian dari hak menguasai negara dimana sebagian kewenangannnya diberikan kepada pemegang haknya. Setelah UU Cipta Kerja diundangkan beberapa ketentuan perihal hak atas tanah menunjukkan perubahan dari segi aturannya, tidak terkecuali adanya penegasan mengenai hak pengelolaan yang dapat terjadi diatas tanah ulayat, hal yang demikian menimbulkan benturan konsep hak pengelolaan dengan konsep tanah ulayat. Mengingat hak pengelolaan merupakan perwujudan sebagian dari hak menguasai negara sebagaimana kandungan dalam Pasal 33 ayat (3) Undang-Undang Dasar 1945 (UUD 1945) jo. Pasal 2 ayat (1) Undang-Undang Nomor 5 Tahun 1960 tentang Peraturan Dasar-Dasar Pokok Agraria (UUPA) dengan tanah ulayat yang merupakan bagian dari hak ulayat masyarakat hukum adat yang keberadaannya diakui dalam Pasal 3 dan Pasal 5 UUPA, maka konsepsi yang demikian perlu dilakukan analisis dengan menggunakan metodologi pendekatan undang-undang dan pendekatan konsep terkait dengan kebijakan pengaturan hak pengelolaan yang berasal dari tanah ulayat. Dengan memperhatikan aturan yang ada dalam UUPA serta konsep hukum dari hak pengelolaan dan tanah ulayat maka perlu adanya pelepasan hak ulayat terhadap tanah ulayat tersebut sehingga tanah ulayat tersebut menjadi tanah negara dan dapat diberikan hak pengelolaan diatasnya.
\end{abstract}

Kata Kunci: Hak Pengelolaan; Tanah Ulayat; Undang-Undang Cipta Kerja. 


\section{Pendahuluan}

Pengaturan mengenai Hak atas Tanah di Indonesia diatur berdasarkan Undang-Undang Nomor 5 Tahun 1960 tentang Peraturan Dasar Pokok-pokok Agraria (UUPA) dimana dalam mengatur kebijakan peruntukan, penggunaan, persediaan dan pemeliharaan bumi, air dan ruang angkasa dikuasai langsung oleh Negara dan diberikan wewenang sebagai organisasi kekuasaan seluruh rakyat Indonesia, penguasaan oleh Negara yang tertuang dalam UUPA tersebut merupakan bentuk tindak lanjut atas dasar ketentuan dari Undang-Undang Dasar 1945 Pasal 33 ayat 3 yang menyatakan bahwa "Bumi, air, dan kekayaan alam yang terkandung didalamnya dikuasai oleh Negraa dan dipergunakan sebesar-besarnya kemakmuran rakyat" sehingga memunculkan Hak Menguasai dari Negara yang ditujukan untuk kemakmuran dan kesejahteraan rakyat. Dari Hak Menguasai Negara tersebut kemudian berkembang dan muncul mengenai Hak Pengelolaan

yang sebenarnya dalam UUPA tidak terdapat istilah Hak Pengelolaan namun terdapat istilah pengelolaan, perwujudan secara tersirat ini terdapat dalam Pasal 2 ayat (4) UUPA dan Penjelasan Umum II angka 2 UUPA “....... Negara dapat memberikan tanah yang demikian itu kepada seseorang atau badan hukum dengan sesuatu hak menurut peruntukan dan keperluannya, misalnya Hak Milik, Hak Guna Usaa, Hak Guna Bangunan atau Hak Pakai atau memberikannya dalam pengelolaan kepada suatu Badan Penguasa (Departemen, Jawatan atau Daerah Swatantra) untuk dipergunakan bagi pelaksanaan tugasnya masing-masing".

Namun sejak diundangkannya Undang-Undang Nomor 11 Tahun 2020 tentang Cipta Kerja (UU Cipta Kerja) serta berlakunya Peraturan Pemerintah Nomor 18 Tahun 2021 tentang Hak Pengelolaan, Hak Atas Tanah, Satuan Rumah Susun, dan Pendaftaran Tanah (PP 18 Tahun 2021) muncul aturan baru perihal pengaturan hak atas tanah di Indonesia dimana salah satu hal penting yang diatur oleh PP 18 Tahun 2021 ingin dibahas oleh peneliti yakni mengenai Hak Pengelolaan yang berasal dari Tanah Ulayat.

Secara konsep Hak Pengelolaan yang diberikan diatas tanah ulayat bertentangan dengan konsep dari Hak Pengelolaan itu sendiri sehingga 
menimbulkan ketidakpastian hukum dalam pemberian Hak Pengelolaan yang berasal dari Tanah Ulayat, hal ini disebabkan karena Tanah Ulayat terikat oleh Hak Ulayat Masyarakat Hukum Adat sehingga ada benturan konsep antara sebagian kewenangan yang diberikan oleh Negara dalam konsep Hak Pengelolaan dengan Hak Ulayat Masyarakat Hukum Adat. Perlu adanya analisis yang mendalam mengenai konsep tersebut, sehingga dari latar belakang masalah inilah peneliti tertarik untuk menganalisis pemberian Hak Pengelolaan yang berasal dari Tanah Ulayat pasca terbitnya Undang-Undang Cipta Kerja.

\section{Metode Penelitian}

Tipe penelitian yang digunakan dalam penelitian ini adalah penelitian hukum, yakni penelitian yang dilakukan untuk menemukan dan mengkaji aturan-aturan hukum, prinsip-prinsip hukum maupun doktrin-doktrin hukum guna menjawab isu hukum yang dihadapi. Penyelesaian masalah hukum dalam penelitian ini menggunakan aturan atau norma yang diatur dalam peraturan perundangundangan yang berlaku sehingga dapat memperoleh kesimpulan yang terkait dengan analisis benturan prinsip Hak Pengelolaan yang berasal dari Tanah Ulayat.

Penelitian ini berlandaskan pada Pendekatan Perundang-undangan (Statute Approach) yang dilakukan dengan menelaah semua undang-undang dan regulasi yang bersangkut paut dengan isu hukum yang sedang ditangani. Dalam hal ini peraturan yang digunakan adalah UUPA, UU Cipta Kerja, PP 18 Tahun 2021 dan peraturan lainnya dalam lingkup hak atas tanah, hak pengelolaan, maupun hak ulayat masyarakat hukum adat. Sedangkan, pendekatan konseptuan (Conseptual Approach) adalah pendekatan yang beranjak dari pandangan-pandangan dan doktrin-doktrin yang berkembang di dalam ilmu hukum, guna menemukan ideide yang melahirkan pengertian, konsep dan asas hukum yang relevan sebagai sandaran dalam membangun suatu argumentasi hukum dalam memecahkan isu hukum yang dihadapi. Dalam penelitian ini penulis menggunakan konsep Hak Menguasai Negara Atas Tanah serta Konsep Hukum Adat sebagai dasar pembentukan UUPA yang kemudian ditarik berdasarkan UU Cipta Kerja. 
Sumber bahan hukum yang digunakan dalam penelitian ini terdiri atas bahan hukum primer dan bahan hukum sekunder. Bahan hukum primer meliputi bahan hukum yang bersumber dari peraturan perundang-undangan yang berlaku dan peraturan lainnya yang berkaitan dengan analisis prinsip Hak Pengelolaan yang berasal dari Tanah Ulayat. Sedangkan bahan hukum sekunder adalah bahan hukum yang bersumber dari literatur dalam perpustakaan dan jurnal online yang berhubungan dengan penelitian ini.

Prosedur penelitian dilakukan dengan mengumpulkan dan mengolah bahan hukum yang dilakukan dengan metode studi kepustakaan melalui membaca serta mempelajari bahan hukum yang memuat informasi berkaitan dengan pokok bahasan konsep hak pengelolaan yang berasal dari tanah ulayat kemudian dilakukan pengelolaan bahan hukum, disesuaikan dengan materi, dan dianalisis sehingga akan memperoleh hasil pembahasan yang dapat dipertanggung jawabkan secara sistematis.

\section{Konsep dan Pengaturan Hak Pengelolaan Sebelum dan Sesudah UU Cipta Kerja}

Hukum Agraria Nasional secara tersurat tidak menyebutkan perihal Hak Pengelolaan, namun disebut sebagai pengelolaan yang termuat dalam Penjelasan Umum Angka II Nomor 2 UUPA. ${ }^{1}$ Menurut Maria S.W. Sumardjono yang dikutip dari Urip Santoso menyatakan bahwa UUPA tidak menyebutkan secara eksplisit perihal Hak Pengelolaan, dari segi diktum, batang tubuh maupun penjelasannya, namun dari segi praktik ditemui keberadaan Hak Pengelolaan dengan dasar hukum yang berkembang. ${ }^{2}$ Efendi Perangin menyatakan Hak Pengelolaan tidak diatur dalam UUPA bahkan tidak menyebut secara terang-terangan mengenai Hak Pengelolaan, ia berpendapat bahwa kata "pengelolaan" yang terdapat di Penjelasan Umum II/2UUPA bukan semata-mata yang dimaksud dengan Hak Pengelolaan. ${ }^{3}$

\footnotetext{
${ }^{1}$ Lihat Penjelasan Umum Undang-Undang Nomor 5 Tahun 1960 tentang Peraturan Dasar Pokok-Pokok Agraria (Lembaran Negara Republik Indonesia Tahun 1960 Nomor 104, Tambahan Lembaran Negara Republik Indonesia Nomor 2043).

${ }^{2}$ Urip Santoso, 'Eksistensi Hak Pengelolaan Dalam Hukum Tanah Nasional' (2012) 24 Mimbar Hukum.[12].

${ }^{3}$ Urip Santoso, Hukum Agraria - Kajian Komprehensif (5th edn, Prenadamedia Group 2015.[152].
} 
Hak Pengelolaan tidak diatur sebagaimana hak atas tanah yang terdapat dalam Pasal 16 ayat (1) UUPA akan tetapi, istilah pengelolaan yang terdapat dalam Penjelasan Umum Angka II Nomor 2 UUPA yang dijelaskan bahwa "Negara dapat memberikan tanah yang demikian itu kepada seseorang atau badan hukum dengan sesuatu hak menurut peruntukan dan keperluannya, misalnya Hak Milik, Hak Guna Usaha, Hak Guna Bangunan dan Hak Pakai atau memberikannya dalam Pengelolaan (garis tebal penulis) kepada suatu badan penguasa (departemen, jawatan atau daerah swatantra) untuk digunakan bagi pelaksanaan tugasnya masing-masing". Daerah swatantra yang disebutkan dalam UUPA tersebut merupakan penerima kuasa dari sebagian Hak Menguasai Negara yang pelaksanaannya dapat dikuasakan kepada Pemerintah Daerah atau Pemerintah Provinsi untuk melaksanakan otonomi daerah. ${ }^{4}$

Secara istilah Hak Pengelolaan merupakan terjemahan dari bahasa Belanda Beheersrechtyang berartiHakPenguasaan, ${ }^{5}$ MariaS.W.Sumardjono dan A.P.Parlindungan sependapat bahwa Hak Penguasaan yang diterjemahkan dari bahasa Belanda tersebut adalah sama dengan yang dimaksud dengan Hak Penguasaan atas Tanah-Tanah Negara yang terdapat dalam Peraturan Pemerintah Nomor 8 Tahun 1953 tentang Penguasaan Tanah-tanah Negara (PP No. 8 Tahun 1953) dimana Hak Penguasaan atas Tanah Negara tersebut diberikan kepada jawatan atau daerah swatantra sebagaimana yang diatur dalam PP No. 8 Tahun 1953). ${ }^{6}$

Hak Pengelolaan ini pertama kali muncul karena adanya kebijakan pemerintah dalam rangka pelaksanaan konversi hak penguasaan atas tanah negara yang berada pada suatu departemen, jawatan atau daerah swatantra. Pertama kalinya kebijakan tersebut muncul dalam Peraturan Menteri Agraria Nomor 9 Tahun 1965 tentang Pelaksanaan Konversi Hak Penguasaan atas Tanah Negara dan Kebijaksanaan Selanjutnya (PMA No. 9 Tahun 1965) yang termuat dalam Pasal 2 yang menyatakan bahwa apabila tanah negara yang diberikan kepada departemen, direktorat dan daerah swatantra, selain

\footnotetext{
${ }^{4}$ Ana Silviana, 'Pemanfaatan Tanah Di Atas Hak Pengelolaan Antara Regulasi Dan Implementasi' (2017) 1 Diponegoro Private Law Review [36].

${ }^{5}$ A. Parlindungan, Hak Pengelolaan Menurut Sistem Undang-Undang Pokok Agraria (3rd edn, Mandar Maju 1989).[6].

${ }^{6}$ Santoso, Hukum Agraria - Kajian Komprehensif (n 3). Op.Cit.[158].
} 
digunakan untuk kepentingan instansi itu sendiri dimaksudkan pula untuk dapat diberikan dengan sesuatu hak kepada pihak ketiga, maka hak atas tanah negara tersebut dikonversi menjadi hak pengelolaan. Sehingga dapat dikatakan bahwa dari ketentuan Pasal 2 PMA No. 9 Tahun 1965 tersebut adalah asal mula lahirnya Hak Pengelolaan. ${ }^{7}$

Keberadaan dan istilah mengenai Hak Pengelolaan sebelum UUPA berlaku disebut dengan Hak Penguasaan atas Tanah Negara yang terdapat dalam PP No. 8 Tahun 1953 yang kemudian oleh PMA No. 9 Tahun 1965 Hak Penguasaan atas Tanah Negara tersebut dikonversi menjadi Hak Pengelolaan. Berkembangnya istilah Hak Pengelolaan kemudian muncul di berbagai peraturan yang meskipun didalam UUPA sendiri tidak mengatur kedudukan dari Hak Pengelolaan itu sendiri.

Pengaturan mengenai keberadaan Hak Pengelolaan yang terdapat dalam berbagai peraturan perundang-undangan dapat dianalisis sebagai berikut:

Tabel 1. Pengaturan mengenai Hak Pengelolaan

\begin{tabular}{|c|c|}
\hline Peraturan & Keterangan \\
\hline $\begin{array}{l}\text { Peraturan Pemerintah No. } 8 \text { Tahun } 1953 \\
\text { tentang Penguasaan Tanah Negara }\end{array}$ & $\begin{array}{l}\text { Pasal } 4 \text { diatur mengenai hak penguasaan } \\
\text { atas tanah dapat diberikan kepada kemen- } \\
\text { terian atau jawatan dan daerah swatantra. }\end{array}$ \\
\hline $\begin{array}{l}\text { Peraturan Menteri Agraria No. } 9 \text { Tahun } \\
1965 \text { tentang Pelaksanaan Konversi Hak } \\
\text { Penguasaan }\end{array}$ & $\begin{array}{l}\text { Dalam Peraturan Menteri Agraria ini me- } \\
\text { netapkan konversi hak penguasaan atas } \\
\text { tanah negara yang diatur dalam Pasal } 2 \\
\text { menjadi Hak Pengelolaan }\end{array}$ \\
\hline $\begin{array}{l}\text { Peraturan Menteri Menteri Agraria No. } 1 \\
\text { Tahun } 1966 \text { tentang Pendaftaran Hak Pakai } \\
\text { dan Hak Pengelolaan }\end{array}$ & $\begin{array}{l}\text { Peraturan ini merupakan penegasan dari } \\
\text { PMA No. } 9 \text { Tahun } 1965 \text { yakni dalam rang- } \\
\text { ka kewajiban untuk mendaftarkan hak } \\
\text { pengelolaan bagi departmen, direktorat, } \\
\text { dan daerah swatantra yang menerimanya. }\end{array}$ \\
\hline $\begin{array}{l}\text { Peraturan Pemerintah No. } 40 \text { Tahun } 1996 \\
\text { tentang Hak Guna Usaha, Hak Guna Ban- } \\
\text { gunan, dan Hak Pakai atas Tanah }\end{array}$ & $\begin{array}{l}\text { PP ini mengatur bahwa Hak Guna Ban- } \\
\text { gunan dan Hak Pakai dapat terjadi di atas } \\
\text { tanah Hak Pengelolaan. }\end{array}$ \\
\hline
\end{tabular}

${ }^{7}$ Agus Sekarmadji., et.al, Dinamika Hukum Agraria Indonesia "Dalam Rangka Memperingati 70 Tahun Guru Kami, Prof. Dr. Sri Hajati, S.H., M.S. (Oemar Moechthar ed, 1st edn, Prenadamedia Group 2020). dalam tulisan Irawan Soerodjo "Apakah Hak Pengelolaan Merupakan Jenis Hak atas Tanah?". [445] 
Peraturan Pemerintah No. 24 Tahun 1997 Diatur dalam Pasal 9 PP ini bahwa Hak tentang Pendaftaran Tanah

Pengelolaan termasuk dalam objek pendaftaran tanah selain Hak Milik, Hak Guna Usaha, Hak Guna Bangunan, Hak Pakai, Tanah Wakaf, Hak Milik atas Satuan Rumah Susun, Hak Tanggungan dan Tanah Negara.

Peraturan Menteri Negara Agraria/Kepala Peraturan ini mengatur dalam Pasal 4 bahBadan Pertanahan Nasional No. 9 Tahun wa dalam rangka permohonan, tanah yang 1999 tentang Tata Cara Pemberian dan dimohonkan adalah tanah Hak PengeloPembatalan Hak atas Tanah Negara dan laan yang sebelumnya melakukan perjanjiHak Pengelolaan an penggunaan tanah dari pemegang Hak Pengelolaan.

Hak Pengelolaan yang diatur di berbagai peraturan perundang-undangan tersebut dalam perkembangan terakhir diatur oleh UU Cipta Kerja dan aturan pelaksanaannya yakni PP 18 Tahun 2021. Penguatan perihal Hak Pengelolaan secara tegas diatur dalam Bagian Keempat Pertanahan Paragraf 2 Pasal 136 sampai dengan Pasal 142 UU Cipta Kerja.

Pasca UU Cipta Kerja diundangkan, kedudukan mengenai Hak Pengelolaan nampak dari aturan-aturan yang ditegaskan dalam PP 18 Tahun 2021. Ruang lingkup Hak Pengelolaan yang diatur dalam PP 18 Tahun 2021 tersebut termasuk mengatur perihal tanah yang dapat diberikan dengan Hak Pengelolaan dimana dalam Pasal 4 dinyatakan bahwa Hak Pengelolaan dapat berasal dari Tanah Negara dan Tanah Ulayat. Perkembangan konsep yang baru dari Hak Pengelolaan pasca UU Cipta Kerja adalah dimana bahwa sebelumnya Hak Pengelolaan merupakan bagian dari Hak Menguasai Negara atas Tanah yang dalam aturan-aturan sebelumnya hanya dapat terjadi diatas tanah negara kemudian oleh PP 18 Tahun 2021 diperluas menjadi Hak Pengelolaan dapat terjadi di atas Tanah Ulayat dan selanjutnya dalam Pasal 5 ayat (2) dinyatakan bahwa Hak Pengelolaan yang berasal dari Tanah Ulayat ditetapkan kepada masyarakat hukum adat.

Aturan mengenai Hak Pengelolaan yang terdapat dalam UU Cipta Kerja dan PP 18 Tahun 2021 dapat dijabarkan dalam tabel berikut: 
Tabel 2. Pengaturan Hak Pengelolaan Pasca UU Cipta Kerja

\begin{tabular}{l}
\hline \multicolumn{1}{c}{ Aturan } \\
\hline UU No. 11 Tahun \\
2020 tentang Cipta \\
Kerja, Bagian \\
Keempat Pertanahan,
\end{tabular}

Paragraf 2 Penguatan

Hak Pengelolaan

\section{Pasal}

Pasal 136

Hak Pengelolaan merupakan hak menguasai dari negara yang kewenangan pelaksanaannya sebagian dilimpahkan kepada pemegang haknya.

(1) sebagian kewenangan hak menguasai dari negara berupa tanah dapat diberikan hak pengelolaan kepada :
a. instansi Pemerintah Pusat;
b. Pemerintah Daerah;
c. Badan Bank Tanah;
d. Badan Usaha Milik Negara/Daerah; atau
e. Badan Hukum yang ditunjuk oleh Pemerintah Pusat.

(2) Hak Pengelolaan sebagaimana dimaksud pada ayat (1) memberikan kewenangan untuk:

a. Menyusun rencana peruntukan, penggunaan dan pemanfataan tanah sesuai dengan rencana tata ruang;

b. Menggunakan dan memanfaatkan seluruh atau sebagian tanah hak pengelolaan untuk digunakan sendiri atau dikerjasamakan dengan pihak ketiga; dan

c. Menentukan tarif dan menerima uang pemasukan/ganti rugi dan/atau uang wajib tahunan dari pihak ketiga sesuai dengan perjanjian

(3) Pemberian Hak Pengelolaan sebagaimana dimaksud pada ayat (1) diberikan atas tanah negara dengan keputusan pemberian hak diatas tanah negara.

(4) Hak Pengelolaan dapat dilepaskan kepada pihak yang memenuhi syarat.

\section{Pasal 138}

(1) Penyerahan pemanfaatan bagian tanah Hak Pengelolaan kepada pihak ketiga sebagaimana dimaksud dalam Pasal 137 ayat (2) huruf b dilakukan dengan perjanjian pemanfaatan tanah.

(2) Di atas tanah Hak Pengelolaan yang pemanfaatannya diserahkan kepada pihak ketiga baik sebagian atau seluruhnya, dapat diberikan hak guna usaha, hak guna bangunan, dan/atau hak pakai sesuai dengan ketentuan peraturan perundang-undangan.

(3) Jangka waktu hak guna bangunan di atas Hak Pengelolaan sebagaimana dimaksud pada ayat (2) dapat diberikan-- 
perpanjangan dan pembaharuan hak apabila sudah digunakan dan/atau dimanfaatkan sesuai dengan tujuan pemberian haknya.

(4) Pemerintah Pusat melakukan pengawasan dan pengendalian atas penggunaan dan/atau pemanfaatan tanah di Atas Hak Pengelolaan sebagaimana dimaksud pada ayat (3) sesuai dengan ketentuan peraturan perundang-undangan.

(5) Dalam hal hak atas tanah yang berada di atas Hak Pengelolaan telah berakhir, tanahnya kembali menjadi tanah Hak Pengelolaan.

\section{Pasal 139}

(1) Dalam keadaan tertentu, Pemerintah Pusat dapat membatalkan dan/atau mencabut Hak Pengelolaan sebagian atau seluruhnya.

(2) Tata cara pembatalan Hak Pengelolaan dilaksanakan sesuai dengan ketentuan peraturan-perundang-undangan.

\section{Pasal 140}

(1) Dalam hal bagian bidang tanah Hak Pengelolaan diberikan dengan hak milik, bagian bidang tanah Hak Pengelolaan tersebut hapus dengan sendirinya.

(2) Hak milik sebagaimana dimaksud pada ayat (1) hanya diberikan untuk keperluan rumah umum dan keperluan transmigrasi.

\section{Pasal 141}

Dalam rangka pengendalian pemanfaatan hak atas tanah di atas Hak Pengelolaan, dalam waktu tertentu, dilakukan evaluasi pemanfaatan hak atas tanah.

\section{Pasal 142}

Ketentuan lebih lanjut mengenai Hak Pengelolaan diatur dalam Peraturan Pemerintah.

Peraturan Pemerintah

No. 18 Tahun

2021 tentang Hak

Pengelolaan, Hak

atas Tanah, Satuan

Rumah Susun dan

\section{Bagian Kesatu}

Tanah yang dapat diberikan dengan Hak Pengelolaan

Pasal 4

Hak Pengelolaan dapat berasal dari Tanah Negara danTanah Ulayat. 
BAB III Hak

Pengelolaan

\section{Bagian Kedua \\ Subjek Hak Pengelolaan \\ Pasal 5}

(1) Hak Pengelolaan yang berasal dari Tanah Negara diberikan kepada:

a. instansi Pemerintah Pusat;

b. Pemerintah Daerah;

c. Badan Usaha Milik Negara/ Badan Usaha Milik Daerah;

d. Badan Hukum Milik Negara/Badan Hukum Milik Daerah;

e. Badan BankTanah; atau

f. badan hukum yang ditunjuk oleh Pemerintah Pusat.

(2) Hak Pengelolaan yang berasal dari Tanah Ulayat ditetapkan kepada masyarakat hrrkum adat.

\section{Pasal 6}

(1) Hak Pengelolaan di atas Tanah Negara diberikan sepanjang tugas pokok dan fungsinya langsung berhubungan dengan pengelolaan Tanah.

(2) Instansi Pemerintah Pusat sebagarmana dimaksud dalam Pasal 5 ayat (1) huruf a yang tugas pokok dan fungsinya tidak langsung berhubungan dengan pengelolaan Tanah dapat diberikan Hak Pengelolaan setelah mendapat persetujuan menteri yang menyelenggarakan urusan pemerintahan di bidang keuangan.

(3) Badan usaha milik negara/badan usaha milik daerahnsebagaimana dimaksud dalam Pasal 5 ayat (1) huruf c meliputi juga anak perusahaan yang dimiliki oleh badan usaha milik negara/badan usaha milik daerah berdasarkan penyertaan modal negara pada badan usaha milik negara/ badan usaha milik daerah lain.

(4) Badan hukum yang ditunjuk oleh Pemerintah Pusat sebagaimana dimaksud dalam Pasal 5 ayat (1) huruf $f$ merupakan badan hukum yang mendapat penugasan khusus yang ditetapkan dengan Peraturan Presiden.

\section{Bagian Ketiga}

Pemanfaatan Tanah Hak Pengelolaan

Pasal 7 
(1) Pemegang Hak Pengeloiaan diberikan kewenangan untuk:

a. menyusun rencana peruntukan, penggunaan, dan pemanfaatan Tanah sesuai dengan rencana tata ruang;

b. menggunakan dan memanfaatkan seluruh atau sebagian Tanah Hak Pengelolaan untuk digunakan sendiri atau dikerjasamakan dengan pihak lain; dan menentukan tarif dan/atau uang wajib tahunan dari pihak lain sesuai dengan perjanjian.

(2) Rencana peruntukan, penggunaan, dan pemanfaatan tanah sesuai dengan rencana tata ruang sebagaimana dimaksud pada ayat (1) huruf a merupakan rencana induk yang disusun oleh pemegang Hak Pengelolaan.

\section{Pasal 8}

(1) Hak Pengelolaan yang penggunaan dan pemanfaatan seluruh atau sebagian tanahnya untuk digunakan sendiri atau dikerjasamakan dengan pihak lain sebagaimana dimaksud daiam Pasal 7 ayat (1) huruf b dapat diberikan Hak Atas Tanah berupa hak guna usaha, hak guna bangunan dan/atau hak pakai di atas Hak Pengelolaan sesuai dengan sifat dan fungsinya, kepada:

a. pemegang Hak Pengelolaan sepanjang diatur dalam Peraturan Pemerintah; atau

b. pihak lain, apabila Tanah Hak pengelolaan dikerjasamakan dengan perjanjian pemanfaatan tanah.

(2) Perjanjian pemanfaatan tanah sebagaimana dimaksud pada ayat (1) huruf b paling sedikit memuat:

a. identitas para pihak;

b. letak, batas, dan luas Tanah;

c. jenis penggunaan, pemanfaatan Tanah, dan/atau bangunan yang akan didirikan;

d. ketentuan mengenai jenis hak, jangka waktu, perpanjangan, pembaruan, peralihan, pembebanan, perubahan, dan/atau hapusi batalnya hak yang diberikan di atas Tanah Hak Pengelolaan, dan ketentuan pemilikan Tanah dan bangunan setelah berakhirnya Hak Atas Tanah;

e. besaran tarif dan $\mathrm{f}$ atau uang wajib t-ahunan dan tata cara pembayarannya; dan 
f. persyaratan dan ketentuan yang mengikat para pihak, pelaksanaan pembangunan, denda atas wanprestasi termasuk klausul sanksi, dan pembatalan/ pemutusan perjanjian.

\section{Pasal 9}

(1) Penentuan tarif dan/atau uang wajib tahunan disesuaikan dengan tujuan dari pemanfaatan, untuk:

a. kepentingan umum;

b. kepentingan sosial;

c. kepentingan pembangunan; dan/atau

d. kepentingan ekonomi.

(2) Penentuan tarif dan/atau uang wajib tahunan sebagaimana dimaksud pada ayat (1) dituangkan dalam perjanjian pemanfaatan Tanah antara pemegang Hak Pengelolaan dengan pihak lain dan tidak boleh mengandung unsurunsur yang rnerugikan para pihak.

(3) Selain ketentuan sebagaimana dimaksud pada. ayat (1) dan ayat (2), penentuan tarif dan/atau uang wajib tahunan didasarkan pada karakteristik peruntukan dan kemanfaatan tertentu secara wajar.

(4) Rumusan tarif dan $\mathrm{f}$ atau uang wajib tahunan yang dikenakan oleh pemegang Hak Pengelolaan ditetapkan oleh Menteri.

\section{Bagian Keempat \\ Terjadinya Hak Pengelolaan}

Pasal 10

(1) Hak Pengelolaan yang berasal dari Tanah Negara atau Tanah Ulayat ditetapkan dengan keputusan Menteri.

(2) Keputusan sebagaimana dimaksud pada ayat (1) dapat dibuat secara elektronik.

\section{Pasal 11}

(1) Hak Pengelolaan sebagaimana dimaksud dalam Pasal 10 wajib didaftarkan pada Kantor Pertanahan.

(2) Hak Pengelolaan terjadi sejak didaftar oleh Kantor Pertanahan.

(3) Pemegang Hak Pengelolaan diberikan sertipikat sebagai tanda bukti kepemilikan Hak Pengelolaan 


\section{Tanah Ulayat Masyarakat Hukum Adat}

Manusia yang berkumpul dan membentuk suatu kelompok dengan pola interaksi yang sama berbentuk satu kesatuan yang disebut sebagai masyarakat dimana secara terus menerus berinteraksi secara khusus membentuk kepribadian khusus secara kontinu dan tegas serta identitas yang kuat didalamnya serta terbungkus dalam suatu norma menurut kebiasaan maka dapat diklasifikasikan sebagai masyarakat hukum adat. Ikatan khusus yang terjadi secara terus menenus tersebut menjadi adat istiadat khas dari masyarakat tersebut sehingga menurut pendapat Teer Haar yang dikutip dari Sri Hajati bahwa masyarakat hukum adat merupakan kelompok masyarakat yang secara teratur dan tetap memiliki otoritas dan kekayaan sendiri. ${ }^{8}$

Pengertian yang disampaikan oleh Teer Haar tersebut membawa pada konsep bahwa masyarakat hukum adat yang memiliki suatu otoritas tersendiri baik secara berwujud maupun tidak berwujud itulah yang disebut sebagai Hak Ulayat masyarakat hukum adat. ${ }^{9}$ UUPA sendiri telah mengakui bahwa Hak Ulayat tidak dapat dilepaskan dari cikal bakal pertanahan di Indonesia yang diakui secara tegas dalam Pasal 3 UUPA yang menyatakan bahwa "dengan mengingat ketentuanketentuan dalam Pasal 1 dan Pasal 2 pelaksanaan hak ulayat dan hak-hak yang serupa itu dari masyarakat-masyarakat hukum adat, sepanjang menurut kenyataannya masih ada, harus sedemikian rupa sehingga sesuai dengan kepentingan nasional dan negara yang berdasarkan atas persatuan bangsa serta tidak boleh bertentangan dengan UndangUndang dan peraturan-peraturan lain yang lebih tinggi".

Menurut Boedi Harsono ${ }^{10}$ keberadaan Hak Ulayat masyarakat hukum adat diakui sepanjang menurut kenyataannya masih ada dengan ketentuan bahwa masih eksisnya Hak Ulayat pada suatu masyarakat hukum adat tertentu hal ini membawa arti bahwa apabila dalam suatu wilayah hak milik perseorangan lebih kuat maka Hak Ulayat akan menjadi hilang dan Hak Ulayat tersebut tidak dapat

${ }^{8}$ Sri Hajati et.al, Politik Hukum Pertanahan Indonesia (Prenadamedia Group 2021).[71]

${ }^{9}$ ibid.

${ }^{10}$ Boedi Harsono, Hukum Agraria Indonesia (Sejarah Pembentukan UUPA, Isi Dan Pelaksanaannya) (Djambatan 2020).[282]. 
dihidupkan kembali demikian pula dalam suatu wilayah dimana sebelumnya tidak ada Hak Ulayat maka tidak akan dilahirkan Hak Ulayat. Selain itu pelaksanaan dari Hak Ulayat tersebut juga dibatasi dengan ketentuan bahwa Hak Ulayat masyarakat hukum adat tidak boleh bertentangan dengan UUPA, kepentingan nasional, Undang-Undang serta peraturan yang lebih tinggi. ${ }^{11}$

Hak Ulayat dalam UUPA tidak jelaskan secara rinci sebagaimana dalam Hukum Tanah Adat dikenal dengan istilah Beschikkingsrecht yang berarti adalah hak yang dimiliki oleh suatu suku dalam suatu wilayah dalam rangka menguasai seluruh tanah dan isinya dalam wilayahnya. ${ }^{12}$ Menurut Boedi Harsono hak ulayat merupakan hubungan dari kewenangan serta kewajiban dari masyarakat hukum adat dengan tanah yang ada dalam wilayahnya dimana hal tersebut sebagai daya dukung kehidupan masyarakat adat didalamnya. ${ }^{13}$

Dari penjelasan-penjelasan tersebut dapat dipahami bahwa tanah ulayat merupakan bagian dari hak ulayat masyarakat hukum adat, meskipun hak ulayat tidak hanya mengenai tanah ulayat (pengertian secara hak pemanfaatan bersama) namun tanah ulayat menjadi dasar dari kehidupan masyarakat hukum adat dengan otonominya masing-masing yang kemudian diartikan sebagai Hak atas Tanah Adat. ${ }^{14}$ Konsepsi dari Hak atas Tanah Adat merupakan hubungan penguasaan atas tanah oleh suatu masyarakat hukum adat kemudian dikenal sebagai hak menguasai yang melekat dalam masyarakat hukum adat dengan tanah ulayat. Menurut Maria S.W. Sumardjono yang dikutip dari Soelistyowati ${ }^{15}$ ada wewenang yang melekat antara masyarakat hukum adat dengan tanah ulayat, antara lain:

a) Mengatur serta menyelenggarakan pemanfaatan, pemeliharaan dan penggunaan tanah yang digunakan sebagai kebutuhan masyarakat hukum adat (pemukiman, bercocok tanam, dan lain sebagainya).

\footnotetext{
${ }^{11}$ Lihat Penjelasan Umum II angka 3 UUPA Pasal 3.

${ }^{12}$ Sri Hajati et.al Buku Ajar Hukum Adat (Prenadamedia Group 2019).[116].

${ }^{13}$ Boedi Harsono, 2020, Op.Cit.[185-186].

${ }^{14}$ Agus Sekarmadji and et.al., Op.Cit.[457].

15 ibid.
} 
b) Mengatur serta menentukan hubungan hukum antara masyarakat (perorangan) dengan tanah adat tersebut dengan memberikan hak tertentu pada subjek tertentu.

c) Mengatur serta menetapkan hubungan hukum antara subjek dengan perbuatan hukum yang berhubungan dengan tanah (jual beli, waris dan lainlain).

Selanjutnya dalam mempertegas pengertian mengenai hak ulayat, dan tanah ulayat itu sendiri dapat mengacu pada Peraturan Menteri Negara Agraria/Kepala Badan Pertanahan Nasional No. 5 Tahun 1999 tentang Pedoman Penyelesaian Masalah Hak Ulayat Masyarakat Hukum Adat. ${ }^{16}$ Dimana dalam Pasal 1 dijelaskan sebagai berikut:

1. Hak ulayat dan yang serupaitu dari masyarakat hukum adat adalah kewenangan yang menurut hukum adat dipunyai oleh masyarakat hukum adat tertentu atas wilayah tertentu yang merupakan lingkungan para warganya untuk mengambil manfaat dari sumber daya alam, termasuk tanah dalam wilayah tersebut, bagi keberlangsungan hidup dan kehidupannya yang timbul dari hubungan secara lahiriah dan batiniah secara turun temurun dan tidak terputus antara masyarakat hukum adat tersebut dengan wilayah yang bersangkutan.

2. Tanah ulayat adalah bidang tanah yang diatasnya terdapat hak ulayat dari suatu masyarakat hukum adat tertentu.

Mengenai ketentuan dari masyarakat hukum adat, dapat mengacu Putusan Mahkamah Konstitusi No. 31/PUU-V/2007 tentang Pengujian Undang-Undang No. 31 Tahun 2007 tentang Pembentukan Kota Tual di Provinsi Maluku terhadap UUD 1945:

${ }^{16}$ Dikutip dari Sri Hajati, et.al Politik Hukum Pertanahan Indonesia Op.Cit. Ketentuan Peraturan Menteri Negara Agraria/Kepala Badan Pertanahan Nasional No. 5 Tahun 1999 tentang Pedoman Penyelesaian Masalah Hak Ulayat Masyarakat Hukum Adat telah dicabut sebagaimana ketentuan terakhir Pasal 25 Peraturan Menteri Negara Agraria dan Tata Ruang/Kepala Badan Pertanahan Nasional No. 10 Tahun 2016 tentang Tata Cara Penetapan Hak Komunal atas Tanah Masyarakat Hukum Adat dan Masyarakat yang berada dalam Kawasan Tertentu. Peraturan terbaru tidak memberikan definisi perihal tanah ulayat dan hak ulayat, sehingga meskipun Ketentuan Peraturan Menteri Negara Agraria/Kepala Badan Pertanahan Nasional No. 5 Tahun 1999 tentang Pedoman Penyelesaian Masalah Hak Ulayat Masyarakat Hukum Adat sudah tidak berlaku untuk mengisi kekosongan hukum (rechtsvacuum) perihal defisini dapat mengacu ketentuan ini. 
"Masyarakat Hukum Adat adalah sekelompok orang yang terikat oleh tatanan hukum adatnya sebagai warga bersama suatu persekutuan hukum karena kesamaan tempat tinggal ataupun atas dasar keturunan".

\section{Prinsip Hak Pengelolaan diatas Tanah Ulayat Pasca UU Cipta Kerja}

Mengacu pada konsep bahwa Hak Pengelolaan merupakan Hak Menguasai Negara atas Tanah yang dapat diberikan kepada suatu badan penguasa (departemen, jawatan atau daerah swatantra) yang digunakan untuk pelaksanaan tugasnya masing-masing dimana kewenangan pelaksanaannya sebagian dilimpahkan kepada pemegang haknya. ${ }^{17}$ Hak menguasai dari negara atas tanah tersebut merupakan sumber dari hak bangsa Indonesia atas tanah yang pada hakikatnya merupakan penugasan pelaksanaan tugas kewenangan bangsa Indonesia dengan kandungan unsur publik didalamnya. ${ }^{18}$

Menurut Boedi Harsono, Hak Pengelolaan tidak termasuk dalam Hak atas Tanah akan tetapi "gempilan" dari Hak Menguasai Negara atas Tanah. ${ }^{19}$ Demikian hal nya dengan pendapat Maria S.W. Sumardjono yang dikutip dari Urip Santoso yang menyatakan bahwa Hak Pengelolaan merupakan "bagian" dari hak menguasai negara yang (sebagian) kewenangannya dilimpahkan kepada pemegang Hak Pengelolaan. ${ }^{20}$

Dalam perkembangannya saat ini Hak Pengelolaan yang diatur dalam PP No. 18 Tahun 2021 mengatur bahwa Hak Pengelolaan dapat diberikan diatas Tanah Negara dan Tanah Ulayat, pengaturan mengenai Hak Pengelolaan yang dapat diberikan diatas Tanah Ulayat apabila ditarik dari konsep dan prinsip dari Hak Pengelolaan adalah bertentangan dengan prinsip dari Hak Pengelolaan itu sendiri.

Konsep dari Hak Pengelolaan yang merupakan pelimpahan "sebagian" dari kewenangan negara tersebut secara prinsip hanya dapat terjadi diatas tanah negara. Ratio legis dari prinsip ini adalah oleh sebab Hak Pengelolaan merupakan kewenangan dari Hak Menguasai Negara maka dari Hak Menguasai

\footnotetext{
${ }^{17}$ Sri Hajati, et.al., Buku Ajar - Politik Hukum Pertanahan (Airlangga University Press 2017). [178].

${ }^{18}$ Urip Santoso, Pendaftaran Dan Peralihan Hak Atas Tanah (Prenadamedia Group 2015).[117-118].

${ }^{19}$ Boedi Harsono, Op.Cit.[280].

${ }^{20}$ Urip Santoso - Hukum Agraria Kajian Komprehensif, Op.Cit.[170].
} 
Negara tersebut memberikan batasan bahwa tanah yang diberikan adalah tanah yang langsung dikuasai oleh negara (tanah negara) yang diberikan kepada subjek hak tertentu. ${ }^{21}$

Tanah ulayat menurut Boedi Harsono yang dikutip dari Agustinus Wiku Setiadi $^{22}$ merupakan bagian dari Hak Ulayat masyarakat hukum adat dimana merupakan hubungan hukum yang konkret antara masyarakat hukum adat dengan tanah dalam wilayahnya. Demikian halnya dengan pendapat A.P. Parlindungan yang menyatakan bahwa tanah ulayat merupakan bidang tanah yang diatasnya terdapat hak ulayat dari masyarakat hukum tertentu..$^{23}$ Dari konsep tersebut tanah ulayat merupakan bagian dari hak ulayat masyarakat hukum adat, ada hak masyarakat hukum adat didalam tanah ulayat tersebut sehingga apabila hal ini ditarik dari pengaturan Hak Pengelolaan pasca UU Cipta Kerja yang mengatur bahwa Hak Pengelolaan dapat diberikan diatas tanah ulayat maka akan bertentangan dengan konsep hak pengelolaan itu sendiri.

Pendapat yang sama diungkapkan oleh Agus Sekarmadji, ${ }^{24}$ menurut Agus Sekarmadji Hak Pengelolaan merupakan Hak Menguasai dari Negara yang kewenangan pelaksanaannya sebagian dilimpahkan kepada pemegangnya sehingga tidak dapat disamakan dengan hak atas tanah yang lain. Oleh sebab merupakan Hak Menguasai Negara yang dilimpahkan sebagian kewenangannya maka pemegang hak pengelolaan memiliki sebagian kewenangan dari hak menguasai negara sehingga menurut Agus Sekarmadji bahwa seharusnya Hak Pengelolaan hanya dapat terjadi diatas tanah negara.

Oleh sebab itu maka dapat dianalisis bahwa mengenai Hak Pengeloaan yang dapat diberikan diatas Tanah Ulayat adalah bertentang dengan konsep Hak Pengelolaan itu sendiri dan bertentangan dengan Hak Ulayat masyarakat hukum

${ }^{21}$ Sri Hajati et.al., Politik Hukum Pertanahan Indonesia, Op.Cit.[143].

${ }_{22}$ Agus Sekarmadji et.al., Dinamika Hukum Agraria Indonesia, dalam tulisan Agustinus Wiku Setiadi "Perolehan Hak Pengelolaan yang berasal dari Tanah Pasini oleh Pemerintah Daerah guna Memenuhi Kepentingan Umum" [400].

${ }^{23}$ ibid.

${ }^{24}$ Agus Sekarmadji, 'Catatan Akhir Tahun Bidang Hukum Pertanahan' www.surabayapagi.com (Surabaya, December 2021) <www.surabayapagi.com>. 
adat karena secara ratio legis ada Hak Ulayat masyarakat hukum adat diatas Tanah Ulayat tersebut serta Hak Pengelolaan merupakan sebagian dari kewenangan dari Hak Menguasai Negara. Selanjutnya menurut Agus Sekarmadji apabila tanah yang ingin diberikan Hak Pengelolaan dengan status masih ada Hak Ulayat masyarakat hukum adatnya maka harus dilakukan pelepasan hak dari masyarakat hukum adat tersebut, dari pelepasan hak tersebut maka Tanah Ulayat akan menjadi tanah negara bebas dan dapat diberikan Hak Pengelolaan atas tanah negara sehingga tidak bertentangan dengan konsepsi dari hak pengelolaan itu sendiri.

\section{Kesimpulan}

Hak Pengelolaan yang berasal dari Tanah Ulayat bertentangan dengan konsep dari Hak Pengelolaan itu sendiri, hal ini disebabkan karena Hak Pengelolaan merupakan pelimpahan sebagian kewenangan Dari Hak Menguasai Negara Atas Tanah sehingga pemegang Hak Pengelolaan menerima sebagian dari Hak Menguasai Negara oleh sebab itu harus terjadi diatas tanah negara apabila terjadi diatas Tanah Ulayat maka hal tersebut bertentangan dengan konsep Hak Pengelolaan sebab Tanah Ulayat masih terikat dengan Hak Ulayat masyarakat hukum adatnya, sehingga apabila ingin diberikan Hak Pengelolaan maka harus dilakukan pelepasan Tanah Ulayat dan menjadikan Tanah Ulayat tersebut menjadi tanah negara bebas.

\section{Daftar Bacaan}

\section{Buku}

Agus Sekarmadji, et.al, Dinamika Hukum Agraria Indonesia "Dalam Rangka Memperingati 70 Tahun Guru Kami, Prof. Dr. Sri Hajati, S.H., M.S. (Prenadamedia Group 2020).

A.P. Parlindungan, Hak Pengelolaan Menurut Sistem Undang-Undang Pokok Agraria (Mandar Maju 1989).

Boedi Harsono, Hukum Agraria Indonesia (Sejarah Pembentukan UUPA, Isi Dan Pelaksanaannya) (Djambatan 2020). 
Sri Hajati et.al, Buku Ajar - Politik Hukum Pertanahan (Airlangga University Press 2017).

- - , Buku Ajar Hukum Adat (Prenadamedia Group 2019).

_ - , Politik Hukum Pertanahan Indonesia (Prenadamedia Group 2021).

Urip Santoso, Hukum Agraria - Kajian Komprehensif (Prenadamedia Group 2015).

- - , Pendaftaran Dan Peralihan Hak Atas Tanah (Prenadamedia Group 2015).

\section{Jurnal}

Ana Silviana, 'Pemanfaatan Tanah Di Atas Hak Pengelolaan Antara Regulasi Dan Implementasi' (2017) 1 Diponegoro Private Law Review 36.

Urip Santoso, 'Eksistensi Hak Pengelolaan Dalam Hukum Tanah Nasional' (2012) 24 Mimbar Hukum.

\section{Laman}

Agus Sekarmadji, 'Catatan Akhir Tahun Bidang Hukum Pertanahan' www. surabayapagi.com (Surabaya, December 2021) www.surabayapagi.com diakses 09 Januari 2022.

\section{Perundang-undangan}

Undang-Undang Dasar Negara Republik Indonesia 1945.

Undang-Undang Nomor 5 Tahun 1960 tentang Peraturan Dasar Pokok-Pokok Agraria (Lembaran Negara Republik Indonesia Tahun 1960 Nomor 104, Tambahan Lembaran Negara Republik Indonesia Nomor 2043).

Undang-Undang Nomor 11 Tahun 2020 tentang Cipta Kerja (Lembaran Negara Republik Indonesia Tahun 2020 Nomor 245, Tambahan Lembaran Negara Republik Indonesia Nomor 6573).

Peraturan Pemerintah Nomor 8 Tahun 1953 tentang Penguasaan Tanah-tanah Negara (Lembaran Negara Republik Indonesia Tahun 1953 Nomor 14, Tambahan Lembaran Negara Republik Indonesia Nomor 362).

Peraturan Pemerintah No. 40 Tahun 1996 tentang Hak Guna Usaha, Hak Guna Bangunan, dan Hak Pakai atas Tanah (Lembaran Negara Republik Indonesia Tahun 1996). 
Peraturan Pemerintah No. 24 Tahun 1997 tentang Pendaftaran Tanah Lembaran Negara Republik Indonesia Tahun 1997 Nomor 59).

Peraturan Pemerintah Nomor 18 Tahun 2021 tentang Hak Pengelolaan, Hak atas Tanah, Satuan Rumah Susun, dan Pendaftaran Tanah (Lembaran Negara Republik Indonesia Tahun 2021 Nomor 28, Tambahan Lembaran Negara Republik Indonesia Nomor 6630).

Peraturan Menteri Agraria Nomor 9 Tahun 1965 tentang Pelaksanaan Konversi Hak Penguasaan atas Tanah Negara dan Kebijaksanaan Selanjutnya.

Peraturan Menteri Menteri Agraria No. 1 Tahun 1966 tentang Pendaftaran Hak Pakai dan Hak Pengelolaan.

Peraturan Menteri Negara Agraria/Kepala Badan Pertanahan Nasional No. 9 Tahun 1999 tentang Tata Cara Pemberian dan Pembatalan Hak atas Tanah Negara dan Hak Pengelolaan.

How to cite: Dewi Nawang Wulan, Veronica Tjokroaminoto , Abdul Ghofur, 'Analisis Hukum Pemberian Hak Pengelolaan yang Berasal dari Tanah Ulayat Pasca Terbitnya Undang-Undang Cipta Kerja' (2022) Vol. 5 No. 1 Notaire. 